\title{
"WHAT WOULD HAPPEN IF A SHELL LANDED HERE NOW?"": CORPOREAL VIOLENCE IN SEAN O'CASEY'S THE PLOUGH AND THE STARS AND THE SILVER TASSIE
}

\author{
"O que aconteceria se uma bomba caísse aqui agora?"2 : Violência Corporal \\ nas Peças The Plough and the Stars e The Silver Tassie de Sean O'Casey
}

\author{
Ketlyn Mara ROSA \\ Trinity College Dublin \\ ketlynrosa@yahoo.com.br \\ https://orcid.org/0000-0003-2098-7482
}

\begin{abstract}
This article deals with the corporeal consequences of violence in two selected works of the Irish playwright Sean O'Casey, The Plough and the Stars (1926) and The Silver Tassie (1928). By focusing on the concepts of analysis of violence brought forth by Sarah Cole, the acts of bodily destruction in O'Casey's works can be understood as portraying enchanted and disenchanted facets. The damage done to the human body is represented in complex ways in both plays as they demonstrate an intentional mixture of these two types of violence. Enchanted violence is perceived with the glorification of sacrifice while the physical consequences of destruction are hidden from sight whereas disenchanted violence insists on pointing out the hurt body, the grotesque side of pain that debunks any sense of heroism from battle. By analyzing passages from the plays in which physical violence becomes the focal point, the historical contexts of each play, the Easter Rising of 1916 and the First World War, are enlightened in a way that puts the body of the participants and their vivid experiences on the forefront, enhancing the sense of wastefulness and loss caused by armed conflicts.
\end{abstract}

KEYWORDS: Irish Theater; Corporeal Violence; War.

RESUMO: Este artigo trata das consequências corporais da violência em duas peças do dramaturgo irlandês Sean O'Casey, The Plough and the Stars (1926) e The Silver Tassie (1928). Os atos de destruição corporal nas obras de O'Casey podem ser entendidos como retratos da violência encantadora e desencantadora, conceitos trazidos pela autora Sarah Cole ao analisar o retrato de atos violentos. Os estragos causados no corpo humano são representados de formas complexas nas duas peças ao demonstrarem uma mistura intencional desses dois tipos de violência. A violência encantadora é percebida como a glorificação do sacrifício ao

\footnotetext{
${ }^{1}$ This line is taken from Sean O'Casey's The Plough and the Stars (O'CASEY, 1957, p. 221-222).

${ }^{2}$ The translation of this line was provided by the author of this article.
} 
mesmo tempo que as consequências físicas da destruição são escondidas do público. Já a violência desencantadora insiste em apontar o corpo ferido, o lado grotesco da dor, que desmistifica qualquer ideia de heroísmo no campo de batalha. Ao analisar passagens das peças nas quais a violência física é o ponto focal, os respectivos contextos históricos, o Levante de Páscoa de 1916 e a Primeira Guerra Mundial, são vistos de uma forma que o corpo dos participantes e suas experiências vívidas são colocadas em primeiro plano, intensificando as noções de devastação e perda causadas pelos conflitos armados.

PALAVRAS-CHAVE: Teatro Irlandês;Violência Corporal; Guerra.

Violence is an active component in human interactions ever since the beginning of civilizations until contemporary times. The specialist in literary modernism, Sarah Cole, observes that "as anthropologists tell us, ancient cultures and religions drew their fuel from violence: acquiring its power, protecting against its ravages, rendering it divine or anthropomorphic, creating rituals and ceremonies to slake or reorient it, finding for it a language and an art" (COLE, 2012, p.3). The devastation brought by violence can be registered in material terms, for instance, in the destruction of architectural structures and even entire cities, but most importantly, in corporeal terms, as the damage to the human body can reach disastrous proportions. In this article, two moments in the history of Ireland will be singled out as markers of violent interactions with severe bodily consequences: the event of the Easter Rising in 1916 and the Irish participation in the First World War. Along with these historical moments, excerpts from two plays by the Irish playwright Sean O'Casey will be analyzed, The Plough and the Stars (1926) and The Silver Tassie ${ }^{3}$ (1928), keeping in mind their connection with Cole's ideas about violence. These discussions will focus on how the human body becomes the vehicle through which the experiences of violence and armed conflicts can be represented with catastrophic consequences to both psychological and physical conditions, bringing the corporeal facet of war to the foreground.

The issue of violence and its effects has a contemporary significance due to the ongoing state of war that the twentieth and twenty-first century have witnessed. Hannah

\footnotetext{
${ }^{3}$ Both plays, The Plough and the Stars and The Silver Tassie, are divided into four acts. The former takes place during the Easter Rising of 1916 and illustrates the themes of political idealism and the consequences of urban warfare for the population. The latter depicts the rise and fall of soldierly pride during the First World War as the wounded body demonstrates the psychological and physical effects of disability in society.
} 
Arendt (1970) critically observes that the discussion of violence and its political ramifications is a complex endeavor but essential to a better comprehension of the expression of power. The struggle for dominance that springs from violent acts becomes part of history, as exemplified in the two historical contexts of O'Casey's plays, inflicting trauma to the collective imaginary of countries and to those physically closer to the conflicts. Following a different approach, Pierre Bourdieu brings the perspective that corporeal use of violence is not the only force that impacts a society struggling for power. The notion of symbolic violence in his works comes across as language is elevated to the status of an agent of dominance (SCHUBERT, 2008). Hierarchical systems and oppressive societal structures are part of this mechanism of symbolic violence that causes as much impairment as the violence to the flesh. Both violent acts on a physical sphere and those less visible, such as a type of psychological conditioning of societies into oppressed positions, are facets of the convoluted phenomenon of violence that shapes the historical legacies of countries.

When discussing violence in artistic representations, Cole puts forth two concepts called enchanted and disenchanted violence, which will aid in the comprehension of the role of violent acts in the two aforementioned plays. According to the author, enchanted violence serves "to provide beauty and imaginative release where there is brutality and suffering. Healing, enriching, creating memorable visual forms to capture terrible realities" (COLE, 2012, p. 40). Enchantment "will refer, most succinctly, to the tendency to see in violence some kind of transformative power" (COLE, 2012, p. 42), avoiding the violated body and focusing on positive metaphors and images of growth and communion. The body in this case is seen as a glorified vehicle for generative violence which advocates that "death must become fruitful, blood must be seen as a nourishing source" (COLE, 2012, p. 143). In opposition to this concept is the notion of disenchanted violence that relies on the "active stripping away of idealizing principles, an insistence that the violated body is not a magic site for the production of culture" (COLE, 2012, p. 42). In corporeal terms, "disenchantment calls upon the hurt body, with its signal fluid, to remind us of its reality and frightfulness. Flesh, wounds, penetration: these provide the core figures for disenchantment" (COLE, 2012, p. 44). Far from removing meaning from violence, disenchantment relates to the grotesque side of consequences, and hints at the 
physical effects of degeneration and waste caused by the violent act.

The first play to be analyzed, The Plough and the Stars, takes place during the Easter Rising of 1916 which historically has certain features that can be linked to Cole's enchanted violence. This relevant event in Ireland was an attempt to establish an independent Irish Republic by mounting an armed insurrection against British rule in the territory. As the Irish academics Máire and Conor Cruise O’Brien (1992, p. 137) explain, "the Rising, which had been intended to be nation-wide, hardly spread beyond Dublin City. The rebels seized and held the General Post Office-which became the command post of Pearse and Connoly". They proclaimed the Republic but "after a week's fighting, and the shelling of the GPO, the rebels surrendered", and fifteen of the leaders were executed (O'BRIEN; O'BRIEN, 1992, p. 141). The discourse of the rebels was infused with appeals of sacrifice for the cause as shown in this excerpt taken from the proclamation of the Republic read at the GPO: "In this supreme hour the Irish nation must, by its valour and discipline and by the readiness of its children to sacrifice themselves for the common good, prove itself worthy of the august destiny to which it is called" (apud O'BRIEN; O'BRIEN, 1992, p. 138). The ideal of giving one's life for the sake of fighting for the country's independence regardless of the devastating consequences and pain that would be generated by this act fits the description of what Cole denominates enchanted violence. She comments that "the Irish Rising of 1916 [...] conjoined violent political conditions with prolific literary imagining" and that "the language that surrounded it was steeped in imagery of blood sacrifice, and its combined aura of tragedy and triumph invited symbolic interpretation in its own day and for subsequent generations" (COLE, 2012, p.131). Turning agonizing violence to the body of the participants into a worthy ideal, without highlighting the possible excruciating damage inflicted upon the participants is a way of transforming grotesque violence into a divine and sublime outcome of the revolution.

Another example of the acknowledgment of the blood sacrifice for the cause of an independent Irish Republic can be observed in W. B. Yeats's play entitled Cathleen Ni Houlihan (1902). As the literary and cultural critic Elizabeth Butler Cullingford (1990, p.4) points out, "Yeats is indeed one of the modern propagandists of the notion of blood sacrifice" as the violent death and self-sacrifice references are abundant in Cathleen. In the play, the old woman enters the Gillane household and invites those willing to join the 
forces, and if necessary, give up their lives for the cause of national liberation. This fierce figure explains that "I have good friends that will help me. [...] If they are put down to-day they will get the upper hand to-morrow" (YEATS, 1922, p. 7), emphasizing the ideology of martyrdom with cherished memories of heroism. She makes a direct call for sacrifice when she says that "They that have red cheeks will have pale cheeks for my sake, and for all that, they will think they are well paid" (YEATS, 1922, p. 8). Although the old woman hints at the impairment of a future life and plans, the positive and fruitful result of the effort is still highlighted as heroism and remembrance will be the martyrs' legacy. The violence in this play has a generative and enchanted appeal, with its direct political allegory of nationalism as inspiration, a characteristic that will be noticed in O'Casey's plays as portrayals of criticism to extreme ideologies.

O'Casey's The Plough and the Stars, with its ill-received fourth night performance, can be interpreted as a representation of disenchanted violence due to its anti-heroic portrayals of armed conflicts. The play was written ten years after the events of 1916, and as the researcher Nicholas Grene (1999, p. 141) mentions, "the Rising was close enough to be freshly remembered and felt by participants and survivors, but far enough away to be hallowed in memory", thus the negative reaction to such demystifying portrayal of 1916. Christopher Murray (1989, p. 223), a renowned authority on twentieth and twenty-first Irish drama, in "The 'Might of Design"” highlights that what O'Casey "deconstructed was the mythology of Cathleen Ni Houlihan" and what he revised "was the accepted view of the 1916 rebellion as heroic and worthwhile", bringing a viewpoint of the consequences of the conflict that are based on disillusionment and waste of lives, especially to those who were not celebrated figures of the occasion but the struggling people caught in the crossfire. O'Casey manages to "unit[e] simple home or domestic life with the world of political violence" (MURRAY, 2001, p. xiii) by placing the everyday life of the Dublin tenement residents side by side with the events of the 1916 rebellion.

One of the most apparent features of criticism of the mythical blood sacrifice in the play is the juxtaposition of excerpts of famous speeches by Pearse and the vivid corporeal consequences of the acts of sacrifice for Irish independence. The silhouette of a man is seen through a window and a voice is heard delivering messages such as "bloodshed is a cleansing and sanctifying thing, and the nation that regards it as the final horror has lost its 
manhood" (O'CASEY, 1957, p. 162), "the homage of millions of lives given gladly for love of country" (O'CASEY, 1957, p. 164), and "we must be ready to pour out the same red wine in the same glorious sacrifice, for without shedding of blood there is no redemption!" (O'CASEY, 1957, p. 164). Such words and ideology match the enchanted and inspiring address of the old woman in Cathleen and serve to motivate the Irish people to place themselves in an honorable position of sacrifice for a greater reason regardless of the effects that will surely be physically materialized in the bodies of the volunteers.

As an effective counterpoint, O'Casey includes striking descriptions of what it looks like, and feels like, to suffer the consequences of self-sacrifice, and at this moment, heroism flees the scene and only sorrow and agony of the body remain. The tenement residents are witnesses to the devastating effects of the Easter Rising as Nora Clitheroe returns from the barricades in the streets with a traumatic impression. She describes the physicality of the violence:

NORA. [...] At th' barricade in North King Street I saw fear glowin' in all their eyes. ... An' in th' middle o' th' sthreet was somethin' huddled up in a horrible tangled heap. ... His face was jammed again th' stones, an' his arm was twisted round his back. ... An' every twist of his body was a cry against th' terrible thing that had happened to him. (O’CASEY, 1957, p. 185).

Nora's visceral description is connected to the disenchanted way of portraying violence which does not flee from the grotesque forms and awfulness of the body in pain. The position of the body is one of the features that calls attention due to its strangeness and unnatural posture as the twists of the body in random directions enhance the gravity of the situation that concludes by the deformity of the face. The violation of the head implicates in the loss of the recognition of unique traits such as identity, personality, and facial reactions and corroborates to the definite state of a lifeless body. Nora continues her description by observing that people were frightened to look at the disrupted body, the repulsive detailed consequence of self-sacrifice that is hardly mentioned in the passionate discourse of recruitment.

Another instance of anti-heroic behavior in the play involves the point of view of an active volunteer in the armed conflict, Lieutenant Langon, who functions as a reminder of how gradual and harrowing is the process of being critically wounded. The painful 
unfolding of his injury is followed by his own distressed remarks:

LIEUT. LANGON. [...] Everyone else escapin', an' me getting' me belly ripped asundher! . . . I couldn't scream, couldn't even scream. . . . D'ye think I'm really badly wounded, Bill? Me clothes seem to be all soakin' wet. . . . It's blood. . . . My God, it must be me own blood! (O'CASEY, 1957, p. 195).

The lack of heroism is hinted by Langon's words when he mentions that in the heated moment of armed clashing, people were saving themselves despite the vows of honor and self-sacrifice. His physical injury, located in the abdomen, and the blood-soaked clothes replace the idea of a glorified and sanitized death with a slow and messy display of pain and agony.

In addition, the depiction of Bessie Burgess's death follows the idea of a disenchanted and progressive process of losing vitality. After she is shot through the window, the stage directions describe her movements: "Bessie jerks her body convulsively; stands stiffly for a moment, a look of agonized astonishment on her face, then she staggers forward, leaning heavily on the table with her hands" (O'CASEY, 1957, p. 215). Her death demonstrates how lifelessness takes over the body and makes it progressively inert by shutting down the senses: "Bessie's body lists over and sinks into a prostrate position on the floor" (O'CASEY, 1957, p. 216), "She ceases singing, and lies stretched out, still and very rigid" (O'CASEY, 1957, p. 217). Bessie dies cursing and scolding those around her and not as a heroic martyr for the cause. The Plough and the Stars exposes the disenchanting consequences of death by self-sacrifice without neglecting the peripheral civilians who are caught in the middle of the conflict.

O'Casey's second play analyzed in this paper is The Silver Tassie, which takes place during the historical context of the First World War, follows the anti-heroic strand of the previous play. The scope of this war that was fought from 1914 to 1918 is described by the historian Peter Hart as "an all-embracing conflict reaching far and wide across the continents. It premiered devilish new weapons and created new methods of mass slaughter" (HART, 2013, p. xx). The increase in the magnitude of death with the arrival of technological means in weaponry and tactics can be connected to the level of ruthless violence of this period, and as the military historian John Keegan remarks, it was a tragic 
circumstance since it "ended the lives of ten million human beings [and] tortured the emotional lives of millions more" (KEEGAN, 1998, p. 3). The Irish experience of this war had its specificities in political terms of acceptance between those who believed that the real cause to be fought was in relation to Ireland's independence and those who believed that the critical period in the world scenario was also worthy of attention. The historian Catriona Pennell argues that "the particularity of the Irish experience was the complicated politics of national and imperial unity" (PENNELL, 2012, p. 47). Although nationalists gave emphasis to the struggle at home, Pennell explains that "nationalist Ireland did enter the war and believed that by endorsing the aims for which the United Kingdom stood honour, freedom and liberty of small nations - Ireland would benefit in practical terms as well as fulfilling a moral duty" (PENNELL, 2012, p. 47). Philip Orr, a military historian, estimates that approximately 200,000 Irish soldiers took part of the war and the outcome of this experience can be seen as "the most costly period in Irish military history" (ORR, 2012, p. 77) in terms of casualties. Such traumatizing moment in the culture of a country is bound to be the focus of innumerable artistic representations that endeavor to make sense of tragedy in mass scale. The Silver Tassie is part of one of these creative attempts that highlights the loss not only of lives, but of the will to live, the destruction of the body as well as the collapse of psychological conditions.

The enchanted discourse of war that was done in order to inspire a feeling of devotion and bravery in the volunteers can be strongly recognized in the First World War recruitment process. One of the tools used at the time was the recruitment posters that have a significant role in visually enticing men to join the cause by relying on traditional values of heroism, chivalry, brotherhood, and responsibility to the country. David Bownes and Robert Fleming, authors involved with the subjects of war, museums, and posters, observe that "the more cheery images, in particular, hardly seem serious enough to convey the enormity of world war with its attendant horrors of destruction and death-an aspect of the conflict that is almost always absent" (BOWNES; FLEMING, 2014, p. 20). One of the examples is a poster printed in Dublin that, as Bownes and Fleming explain, "features a large number of Irish soldiers smiling and raising their caps in a welcome to potential new recruits" (BOWNES; FLEMING, 2014, p. 79). The writing on the poster "Come \& join this happy throng - off to the front" demonstrates an attempt to romanticize the war 
experience with allures of brotherhood and amusement, evoking an enchanted atmosphere in a space of desolation. A second example of a poster relies on a very specific case of a heroic soldier, Sergeant Michael O'Leary, who has received the Victorian Cross and now stands as an example to be followed by others. In the poster, his figure in uniform is inserted in the middle of the medal itself, blending his military image with the symbolism of valor brought forth by the medal and crystalizing the message of duty and its consequential state of glory. The idea of heroism stems also from the writing on the top of the poster, "1 Irishman defeats 10 Germans", as a tale to be told of courage and determination. The peer pressure emerges with the question "Have you no wish to emulate the splendid bravery of your fellow countryman?". The poster is a call to arms itself since the encouraging sentence at the bottom, "Join an Irish regiment today" is displayed in a large red font. The enchantment comes from the chance of going through valorous experiences that will display the volunteer's passion for his country and moral force, and earn him a medal of honor at the end. The only problem is that nowhere in the poster there is the acknowledgment of the already experienced horrors of many other soldiers who were not lucky enough to return home alive in order to receive a medal for their bravery.

O'Casey's The Silver Tassie is an artistic representation of the war that diverges from this inspirational interpretation and portrays a conflict populated by disenchantments, both physical and psychological. Rejected by the Abbey Theater, the play eventually premiered at the Apollo Theater in London. Although O'Casey did not have any actual experience in the battlefield of the First World War, he had some contact with soldiers at St. Vincent Hospital in Dublin. The drama scholar James Moran describes that the playwright "witness[ed] at first hand the sufferings of the gassed, the shell-shocked and the maimed" (MORAN, 2013, p. 72). Moran also points out that the play includes a point of view based on the war reports that O'Casey had contact with at the hospital wards, which demonstrated the dichotomy of "young and healthy bodies of athletic men before the war, and the destruction of the front" (MORAN, 2013, p. 72). The experience of immersion into the reality of an environment of loss and pain translates into a grounded perspective of corporeal damage throughout the play that reverses the fascination of brave acts of war into a disillusioned state of powerlessness.

The sense of disenchantment can be perceived in the play through the journey of 
the main character, Harry Heegan, who goes from a hero of the community to a bitter disabled veteran. In act 1 Harry scores the goal that wins the soccer match and is hailed as the popular figure of the team and the bearer of the silver tassie. It is in act 2 that the atmosphere of war will forever change the lives of those who participate in the combat. In an expressionist mode, the second act presents mainly soldiers who are identified by numbers or rank who roam around the destroyed landscape in desolation and fatigue. Moran points out that certain parts of the play are set in a "symbolic hell in which everything is a little 'distorted' from reality" (MORAN, 2013, p. 76). The stage directions regarding the set in the playtext are relevant to the creation of the disenchanted environment: "In the war zone: a scene of jagged and lacerated ruin of what was once a monastery. [...] Here and there heaps of rubbish mark where houses once stood. From some of these, lean, dead hands are protruding" (O'CASEY, 1965, p. 47). The oppressive surroundings denote the grotesque depiction of a combat zone in which architectural structures are turned into ruins, just as the soldiers who will come back home physically and emotionally shattered, which can be compared to the broken china in Teddy Foran's smashing spree of objects in act 1 . The corporeal reference of "protruding" dead hands is a clear sign of violence to the body and an indication of the damage done to the soldiers. This image of mutilation blends into the environment of war, becoming something commonplace and acceptable just as the eerie image evoked by the soldier called Croucher: "can this exceeding great army become a valley of dry bones?" (O'CASEY, 1965, p. 48). The answer to that question is the removal of the corporeal ability of the soldiers:

CROUCHER. [...] the breath came out of them, and the sinews came away from them, and behold a shaking, and their bones fell asunder, bone from bone, and they died, and the exceeding great army became a valley of dry bones. (O'CASEY, 1965, p. 48).

The decorporealization of the soldiers, turned from living flesh to lifeless bones, is a disenchanted metaphor of the consequences of violence in the lives of the war participants.

The imagery of the "dead hands" in the stage directions evokes a shared motif of the significance of the touch in First World War literature. The tactile experience caused 
by the direct immersion of the soldiers into a world of mud, trenches and sand is highlighted, for instance, in the poetry of Wilfred Owen or Siegfried Sassoon as a way of apprehending the world around, its "size, texture, temperature, weight, hardness/softness, viscosity, depth, flatness, movement, composition and space" (DAS, 2008, p. 21). Santanu Das, a specialist on literature of the First World War, explains that "modern technological warfare may be said to represent the ultimate de-personalisation and perversion of this intimate sense as bodies are ripped apart by industrial weaponry" (DAS, 2008, p. 23), a description that fits the context of O'Casey's stage directions in the play. The depiction of "dead hands" that are no longer fit for the function of tactile responsiveness reappear in later First World War representations, such as the classic portrayal of severed hands clutching the barbed wire in Lewis Milestone's All Quiet on the Western Front (1930), an acknowledgement of the intensive tactile sphere of the war and its eminent dissolution through violence.

The somatic focus on Harry's loss of corporeal ability from act 3 onward is the mark of the disenchanting consequence of volunteering into an armed conflict. Harry appears in a wheelchair and his mood is of frustration with his lifeless legs that do not function in the same healthy and youthful way prior to the war. The disillusionment of going into combat and coming back with a physical disability, thus losing his love interest, Jessie Taite, to his friend Barney Bagnal, takes its toll as Harry talks about his legs in a sorrowful tone: "And legs were made to dance, to run, to jump, to carry you from one place to another; but mine can neither walk, nor run, nor jump, nor feel the merry motion of a dance" (O'CASEY, 1965, p. 89). Along with Teddy, who has lost his sight in battle, they complain about their disabilities and loss of vitality:

\footnotetext{
HARRY. I can see, but I cannot dance. TEDDY. I can dance, but I cannot see. HARRY. Would that I had the strength to do the things I see. TEDDY. Would that I could see the things I've strength to do. (O’CASEY, 1965, p. 98).
}

The focus on the injured body moves away from any chance of healing or growth, indicating only an accommodation towards the inevitable pain and inability of the maimed body. The excruciating corporeal violation in this case causes a rupture in physical terms 
and in the personal integrity, that is, a psychological trauma of identity in which the veteran no longer feels comfortable or recognizes his own life but instead faces a devastated everyday interaction with the world.

In conclusion, O'Casey's plays demonstrate a great potential to take apart traditionally accepted ideologies of blood sacrifice and heroism and expose the corporeality behind the myth by emotionally and physically maiming characters in direct contact with violence. The analysis of the excerpts of both plays demonstrates that the two notions regarding violence put forth by Cole, enchanted and disenchanted violence, are actively present in both texts. As they are contrasted through the dialogues and actions of different characters, these concepts highlight on the one hand the senseless ideological extremism and fictitious state of heroism while on the other hand provide details of the graphical state in which the bodies return after the violent experiences. The unending nature of violence during these war embattlements can be exemplified in Arendt's words when she says that "the practice of violence, like all action, changes the world, but the most probable change is to a more violent world" (ARENDT, 1970, p. 80). In the two analyzed plays, the cyclical mode of violence and its ruthless effects, either related to the Easter Rising or the Great War, caused a massive amount of destruction in general, but most importantly, in the everyday lives of the civilians and volunteers. Their names do not prominently feature in history books or newspaper headlines, but they are the ones who viscerally suffer the shattering consequences in their bodies and minds.

\section{REFERENCES}

ARENDT, H. On Violence. Florida: Harvest/HBJ, 1970.

BOWNES, D.; FLEMING, R. Posters of the First World War. Oxford: Shire, 2014.

COLE, S. At the Violet Hour: Modernism and Violence in England and Ireland. Oxford: Oxford University Press, 2012.

CULLINGFORD, E. B. "Thinking of Her. . . as. . . Ireland": Yeats, Pearse and Heaney. Textual Practice, v. 4, n. 1, p. 1-21, 1990.

DAS, S. Touch and Intimacy in First World War Literature. Cambridge: Cambridge University Press, 2008. 
GRENE, N. The Politics of Irish Drama: Plays in Context from Boucicault to Friel. Cambridge: Cambridge University Press, 1999.

HART, P. The Great War: A Combat History of the First World War. Oxford: Oxford University Press, 2013.

KEEGAN, J. The First World War. London: Random House, 1998.

MORAN, J. The Theater of Sean O'Casey. London: Bloomsbury, 2013.

MURRAY, C. Sean O'Casey: The Plough and the Stars. London: Faber and Faber, 2001. . The 'Might of Design' in The Plough and the Stars. In: KOMESU, O.; SEKINE, M. (Orgs.) Irish Writers and Politics. Gerrards Cross: Colin Smythe, p. 223-236, 1989.

O'BRIEN, M.; O'BRIEN, C. C. Ireland: A Concise History. London: Thames and Hudson, 1992.

O'CASEY, S. The Plough and the Stars. In: Three Plays. New York: St Martin's Press, p.131-218, 1957.

O'CASEY, S. The Silver Tassie. In: Three More Plays by Sean O'Casey. London: Macmillan, p. 17-113, 1965.

ORR, P. 200,000 volunteer soldiers. In: HORNE, J. (Org.) Our War: Ireland and the Great War. Dublin: RTÉ, p. 63-77, 2012.

PENNELL, C. Going to war. In: HORNE, J. (Org.) Our War: Ireland and the Great War. Dublin: RTÉ, p. 35-48, 2012.

SCHUBERT, J. D. Suffering. In: GRENFELL M. (Org.) Pierre Bourdieu: Key Concepts. Durham : Acumen, p. 183-198, 2008.

YEATS, W. B. Cathleen Ni Houlihan. In: Plays in Prose and Verse. London: Macmillan, p. 1-10, 1922.

Recebido em: 24 jun. 2020.

Aceito em: 03 ago. 2020. 